\title{
The creation of a concept of one's own life by adolescents as a manifestation of subjectivity and autonomy
}

\begin{abstract}
The article discusses the creation by young people of a concept of their own lives during adolescence, which is treated as a sign of their subjectivity and autonomy. What was emphasised therein was the significant relationship between the creation of the own life concept by adolescents and their overall development during adolescence (development of thinking, personality, value system, future perspectives and social development). Deliberations were based on the theoretical concepts of Piaget (1970) and Niemczyński (1980, 1988), as well as in the empirical studies of Nuttin (1980), Nurmi (1991), Zaleski (1991), Trempała (1996, 2000), Liberska (2004), Katra (2008), and Czerwińska-Jasiewicz (1997, 2005, 2015). An extended author's own model of the creation of an own life concept by adolescents was also presented (Czerwińska-Jasiewicz, 2015). This model indicates the main elements of the own life concept of adolescents (preferred lifestyle, goals and life plans as well as decisions concerning their future) and the main factors that have an impact on the creation of this concept by them (value system, social factors, factors related to general development, and individual characteristics). Conclusions formulated on the basis of the author's own research were also presented (CzerwinskaJasiewicz, 1997 2005, 2015). Further considerations constituted an attempt to substantiate the contention that the creation of the concept of their own lives by adolescents is a manifestation of their subjectivity and autonomy.
\end{abstract}

Key words: adolescence, adolescents, general development, subjectivity, autonomy, concept of own life

\section{Introduction}

The creation of a concept of their own life by adolescents is a specific and universal action of adolescents during adolescence. It is connected both with the general development of adolescents (their thinking, personality, and social development), as well as with such developmental tendencies during this period in life as the "growth" of adolescents into adult society (Inhelder, Piaget, 1970), and searching for their own place in society (Erikson, 1997). The creation by adolescents of their own life concept is also enhanced by both the developmental tasks of adolescence (Havighurst, 1972), and such processes like greater selfawareness, self-cognizance and self-determination and, most of all, the strong needs during this stage, for instance, the need for subjectivity (Inhelder, Piaget, 1970), autonomy and independence (Obuchowska, 2000; Oleszkowicz, Senejko, 2013; Czerwińska-Jasiewicz, 2005, 2015).
I will endeavour to present in this study the significant actions of young people during adolescence which include the creation of the concept of their own life as a manifestation of their subjectivity and autonomy and to substantiate this thesis.

\section{Subjectivity and autonomy - an analysis of concepts}

Subjectivity and autonomy are the main concepts that will be analysed in relation to the main issue in my considerations concerning the creation by adolescents of a concept of their own life treated as a manifestation of their subjectivity and autonomy. Sound support for this thesis requires the definition of the terms of subjectivity and autonomy. How exactly are these concepts understood in psychological literature?

\footnotetext{
Cardinal Stefan Wyszyński University in Warsaw, Faculty of Christian Philosophy, Institute of Psychology

Corresponding author: marylacj@psych.uw.edu.pl
} 
The Subject in dictionary terms (cf. Podsiad, Więckowski 1983, Col. 273) is a feeling or acting human being. The subject of psychological study is the sense of being the subject. What is important in psychology is the personal experience and feeling of the fact that one is the subject. The following ways of approaching the issue of "being the subject" can be identified (Adamiec, 1992): 1) popular, occurring in typical situations (e.g., thinking about different problems); 2) focusing on "that" (on the phenomena of the outside world); 3) expressing oneself, manifest in the creation of the concept of self, in selfreflexivity, and in inner dialogue.

Subjectivity according to Reykowski (1988) is primarily subjective activity which is driven by the goals selected or created by the subject. Subjective activity gives a person their individuality.

The concept of subjectivity is closely linked to the concept of autonomy. According to Obuchowski (1977), the autonomy of the personality constitutes the criterion for the development of the subjectivity of every person in the social life space. Autonomy, according to Obuchowski (1977), above all signifies the independence of the individual from somebody or something. It assumes that the human "self" is attained in the process of individuation and with the participation of other persons. The psychological maturing of the human person can be deemed as a process of moving from the state of social dependence to independence in terms of the formulation of life goals and tasks (Obuchowski, 1977). The attainment of psychological and social autonomy lasts a lifetime and is directed at different needs depending on the stage of development.

Niemczyński $(1980,1988)$ points to the ongoing development of autonomy accompanying general development. An intensive development of autonomy can be noticed in adolescence, particularly in adolescents' designs for their own future. These designs are individual and subjective in nature. However, it is only in early adulthood that these visions of their own life become integrated with the social and historical context, that is, with actual reality.

Straś-Romanowska (1999) notices that the changes in a person's personality are a sign of the individuation process and the advancing autonomy of the individual. They result from the continuous reconstruction of the personal experience content.

The level of self-consciousness grows during adolescence due to the general development taking place in various areas. The individuation process is intensive (Jarymowicz, 1988). Such psychological needs as the need for autonomy and independence start to dominate (Czerwińska-Jasiewicz, 2015; Oleszkowicz, Senejko, 2013). Young people begin to strive with an increasing awareness to being an equal subject in relations with adults (Inhelder, Piaget, 1970). They put increasingly more effort in their current actions and those concerning their own future into being a subject that is autonomous and independent of other people (Czerwińska-Jasiewicz, 2005, 2015).

\section{Creation by the person of the concept of their own life - views of selected authors}

The views of two authors: Piaget (1970) and Niemczyński $(1980,1988)$ are of particular importance in the considerations concerning the creation by adolescents of their own life concept.

Piaget (1970) was a psychologist whose concept on the creation by adolescents of a programme (project) of their own life during adolescence is particularly noteworthy. The fundamental criterion of adolescence for Piaget (1970) was "growth" into a society of adults. According to him, this term means that the adolescent begins to consider her/himself as a person that is equal to adults and begins to judge themselves on the basis of this equality and reciprocity. The adolescent begins to think intensively about his/her own life "programme" (project), which is connected with searching for their individual place in society (Erikson, 1997). Finding this place allows the young person to not only overcome the identity crisis and determine themselves but also constitutes a prerequisite of the process of "growth" into the adult society (Inhelder, Piaget, 1970).

According to Piaget (1970), two aspects are crucial in the process of "growth" into the society of adults: 1) Apart from affections for people, feelings connected with ideals also appear (13-15 years of age); 2) Young people create a programme (project) of their own life.

The own life project of an adolescent, according to Piaget, is based on a specific scale of values on which they place certain ideals and goals higher than others. This becomes possible through the intensive development of the individual value system during adolescence.

In the presented views of Piaget, the striving of young adults to subjectivity in relations with others and in undertaken actions to obtain autonomy is evident. He emphasises that adolescents create their own life project in a subjective and autonomous manner and that this constitutes an original project of an adolescent's life. The main criterion for adolescents creating this project is considered by Piaget to be the individual value system of young persons.

These are highly significant statements. The emphasis of the subjectivity and autonomy of adolescents in the process of creating the project of their own life was particularly valuable to me. Thus, the views of Piaget were an inspiration for me in developing this original model of the life concept of adolescents.

Niemczyński $(1980,1988)$ introduced the term "own life concept" in his studies relating to the psychological models of human development in the life course, thus, throughout their entire life. The creation of the own life concept begins, according to Niemczyński (1980, 1988), in adolescence but occurs particularly intensively and in a more conscious and mature manner in early adulthood. This process lasts a lifetime and is subject to gradual modification during the life course due to the socio-cultural context that influences human development and functioning in adulthood. This approach to the concept concerning 
one's own life is in line with the life-span developmental psychology of Baltes (Baltes, Reese, 1984).

During adolescence, in the opinion of Niemczyński (1980, 1988), adolescents develop a project of the structure of themselves as subjects of actions in the system of programmes and goals individually created by them. The process of personalisation of human actions occurs in adolescence. An adolescent possesses many goals and programmes which is why they face the necessity of putting them in hierarchical order. The next two phases of personalisation occur during early adulthood. During this time, Niemczyński believes that it is no longer adolescent projects but the concept of one's own identity and vision of the comprehensive shape of their life that start to fulfil the function of centres of coordination and integration of human actions.

I would like to stress that the views of Niemczyński were a significant inspiration in my thinking on the creation by adolescents of a concept of their own life during adolescence. Similar studies about the creation by persons of their own life concept are difficult to come by in Polish psychological research. The views of Obuchowski (1995) concerning the search for meaning in life by persons and the phases of this process are, to an extent, similar. This topic is highly significant from the point of view of life-span developmental psychology, which is why it is surprising that so there are so few theoretical studies and empirical research on this matter available in both Polish and foreign literature.

It should also be noted that the views of Niemczyński (1980, 1988) and Piaget (1970) presented above were theoretical in nature. These authors not conducting any empirical studies on the concept of a person's own life. These views were highly significant for my thinking about the own life concept of adolescents and constituted a strong theoretical foundation for the model propounded by me.

It should be stressed that there now is a real lack of both more general theoretical concepts and empirical research concerning the concept of adolescents about their own life.

\section{General development during adolescence and the creation of one's own life concept by adolescents}

The creation by adolescents of a concept of their own life is closely related to their general development during adolescence, mainly with the development of their thinking, personality, value system and worldview as well as their social development and the development of the future orientation (Czerwińska-Jasiewicz, 2015). I will attempt to substantiate this later.

Of vital importance to the process of creation of a life concept by adolescents is the development of formal (operational) thinking during adolescence. It is exactly the development of abstract thinking that allows adolescents to realistically look ahead even into the distant future and create mental representations of future, currently nonexistent states of affairs and put themselves in the future (Inhelder, Piaget, 1970; Zaleski, 1991). The development of formal thinking also facilitates the development of future time perspectives (Nuttin, 1980; Zaleski, 1991) and the future orientation (Nurmi, 1991). The formulation of distant life goals, life plans and decisions concerning the future significantly depends on the development of future time perspectives (Nuttin, 1980; Nurmi, 1991; Zaleski, 1991; Czerwińska-Jasiewicz, 1997, 2005, 2015).

The intensive development of personality, selfcognizance, the concept of self and of identity during this life stage is also crucial to the creation of the concept of life by adolescents. All these processes are closely tied to formal thinking during adolescence (Czerwińska-Jasiewicz, 2015). The development of self-consciousness and the process of self-cognizance are conducive to the creation of a concept of one's own life. The creation of an own life concept by adolescents is possible only when they are capable of determining themselves and responding to two fundamental questions: who am I? And who can I be? (Erikson, 1997). In order to answer these questions, adolescents have to reach an appropriate level of development of self-knowledge (create a certain system), specify the concept of self, and maturely specify their identity (Czerwińska-Jasiewicz, 2015). The individuation process is also important (Jarymowicz, 1988), which means becoming a separate person, a subject. This is connected with strong needs of the adolescence stage like the need for autonomy and independence from other people (Obuchowska, 2000; Oleszkowicz, Senejko, 2013; Czerwińska-Jasiewicz, 2015).

The main criterion of adolescents creating a concept of their own life is their individual value system (Inhelder, Piaget, 1970). This is why the process of creation of the system of values in adolescence is so crucial. Not only is the value system the main criterion for the creation by adolescents of a general concept of one's own life but also the main selection criterion of the preferred lifestyle, the formulation of life goals, the creation of life plans and taking decisions concerning their own future (Czerwińska-Jasiewicz, 2015).

Social development during adolescence is also important in the process of creating a concept of one's own life by young people. Two processes which are closely connected with social development are the most important: the process of "growth" of adolescents into adult society (Inhelder, Piaget, 1970) and the process of searching for one's individual place in society (Erikson, 1997). This mostly is the desire to find one's own place in society and the want to enter this society as a separate subject and one one's own terms (autonomously) that, in my opinion, are the main motives of the creation of a concept of one's own life by adolescents.

I will endeavour to substantiate this thesis further on in these deliberations.

\section{Author's own extended model of adolescents own life concept}

I already pointed out earlier the contemporary lack of both general theoretical concepts and empirical research concerning adolescent's concept of their own life. This 
is the reason why I have proposed an original model for the creation of one's own life concept by adolescents. My theoretical model also constitutes the basis for empirical research about the own life concept of adolescents, which I have been conducting since the year 2000 until the present day, thus, for a period of more than 16 years.

The main theoretical inspiration for my model of adolescent's concept of their own life was the earlier presented views of Piaget (1970) and Niemczyński (1980). The empirical inspiration was drawn from numerous research programmes concerning elements of the adolescent's own life concept propounded by me: life goals (Zaleski, 1991; Liberska, 2004), life plans (Mądrzycki, 2002; Katra, 2008), decisions concerning own future (Rydz, 1995; Czerwińska-Jasiewicz, 1997), as well as the broader theoretical concepts and research programmes concerning the future orientation of the person: Nuttin (1980), Nurmi (1991, 1994), Zaleski (1991, 1994), and Trempała (1996, 2000, 2002).

The first attempt of presenting the model of the own life concept of adolescents was made by the author in her book which was published in 2005 (CzerwińskaJasiewicz, 2005). However, this attempt was preliminary and general. The general theoretical model formed the basis of the first attempts of conducting empirical research concerning adolescent's concept of their own life and its main elements: preferred lifestyles, life goals, life plans, and decisions concerning one's own future. The main criterion that was adopted for the creation of a concept of one's own life by adolescents was their value system, in line with the views of Piaget (1970). In the book published in 2015 (Czerwińska-Jasiewicz, 2015), I made an attempt to deepen the model and extend it by additional significant factors in the process of adolescents creating a concept of their own life, such as: social factors, the level of general development and individual characteristics.

I will present in this study an outline of the author's own extended model of adolescent's concept of their own life and an analysis of the development process of this concept by adolescents as a manifestation of their subjectivity and autonomy.

\section{Definition issues}

How is "adolescent's concept of their own life" understood in this study? Literature on the subject gives no definitions of the term "concept of own life", which is why I have undertaken an attempt to define this term. In my understanding, the adolescent's concept of their own life constitutes of an own life conceptualisation performed by adolescents on the basis of their value system and other individual and social factors (Czerwińska-Jasiewicz, 2015, pp. 154-155).

The creation of a concept of one's own life by adolescents is, in my view, closely related with the process of idealisation (Macnamara, 1990, quoted after: Niemczyński, 2000). According to Macnamara, the idealisation process consists of mentally reaching the ideal and attempting to interpret it. This is possible thanks to the human mind's ability to conceptualise. In the case of the own life concept of adolescents, I consider own future to be a highly specific ideal. The conceptualisation of the ideal of one's own future takes place in the mind of a young person because it concerns future states, which are currently nonexistent and are anticipated in the mind (cf. Czerwińska-Jasiewicz, 2015, p. 155).

According to me, the concept of one's own life first possesses a general nature, being a specific, general "vision" of one's own life. With time, once the adolescent starts trying to fulfil it, it becomes more and more concrete. Adolescents set themselves subsequent, more and more specific questions: How do I want to live? (This is a question about lifestyle and its form); What are my main life goals? How can I fulfil them? (These are questions concerning life plans); What decisions must I take in order to fulfil my life goals and plans? This line of thinking has led me to identify the main elements of adolescent's concept of their own life, which include: the preferred lifestyle, life goals, and life plans and decisions concerning one's own future.

\section{Extended author's own model of adolescent's concept of their own life}

Figure 1 shows the basic elements of the own life concept of adolescents in correlation with each other, as well as the main factors on which the process of adolescents creating this concept is dependent (quoted after: Czerwińska-Jasiewicz, 2015, pp. 168-170).

It must be clearly stated that the model presented in Fig. 1 is hypothetical and theoretical in nature. It constitutes an attempt at presenting an ideal model and ideal course of the process of creation of this concept. However, the model was verified gradually through empirical research on elements of the own life concept of adolescents (lifestyle preferred by them, their life goals and plans, as well as life decisions) as well as the relationships existing between them. These studies were conducted by me personally and by my master's and PhD students for 16 years (since 2000) and have enabled me to gather the relevant knowledge and gain a greater insight into the concept of adolescent's own life as well as the course of its creation process.

The main elements of adolescent's concept of their own life presented in Figure 1 are as follows (cf. Czerwińska-Jasiewicz, 2015, p. 168):

1) Lifestyle (preferred and lived),

2) Life goals (for various stages in life),

3) Life plans (ways of fulfilling goals),

4) Life decisions (concerning one's own future).

The listed elements of adolescent's concept of their own life can be defined as follows:

Life style is understood in literature as the preferred or individually lived lifestyle or a model thereof (Mądrzycki, 2012; Matusewicz, 1975; Hejnicka-Bezwińska, 1991). Psychologists are mainly interested in individual lifestyles. Mądrzycki (2002, 1996, p. 167) developed the most modern psychological definition of the lifestyle concept. According to him, lifestyle is "a relatively fixed proportion and organisation of everyday activities oriented on the present 
Figure 1. Extended author's own model of adolescent's concept of their own life (Factors affecting the creation of this concept and main elements of the concept)

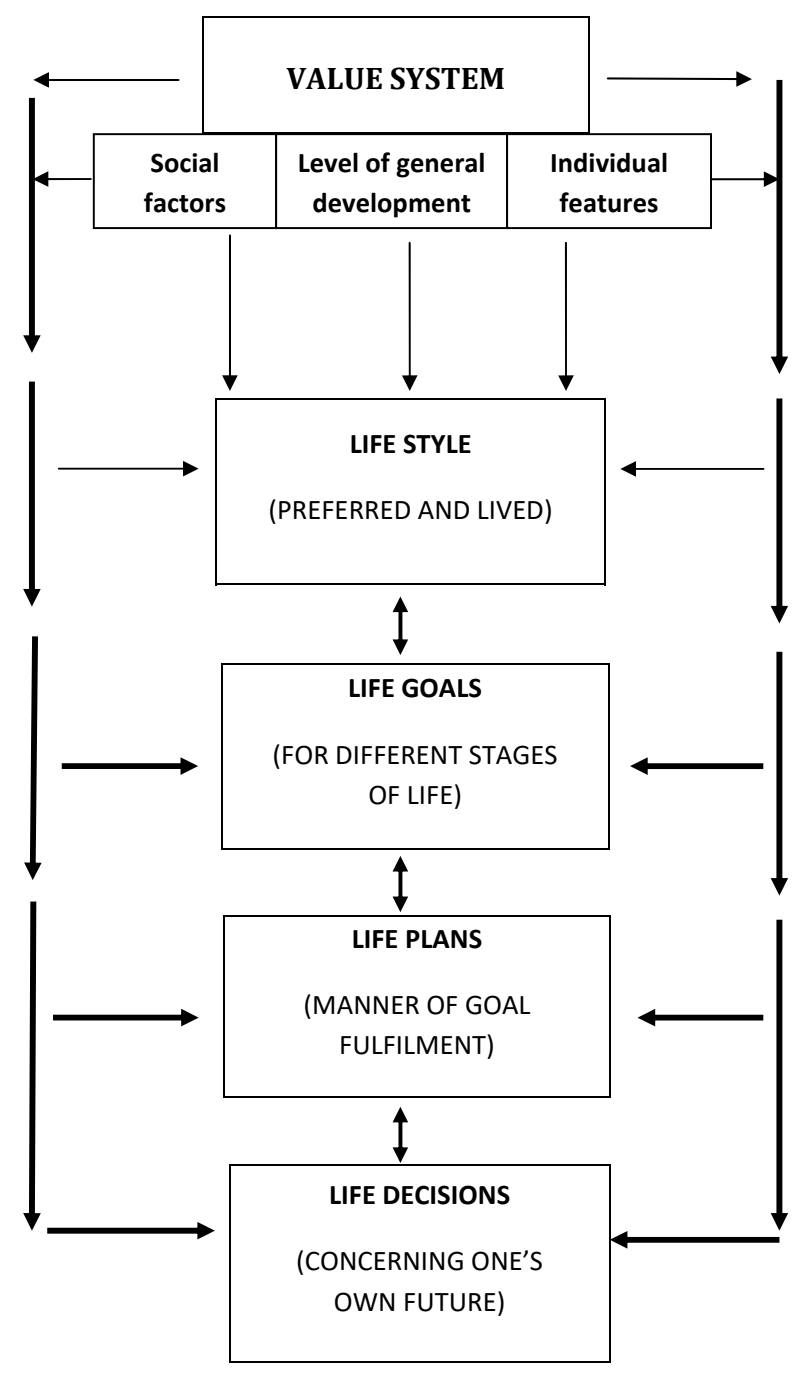

Source: based on: Czerwińska-Jasiewicz, 2015, p. 169.

and directed towards the future, along with their motivating conditionality and relation to the world of things".

Life goals are defined as future states of things that are of significant value and strongly motivating for the human person, which they strive to fulfil through actions (Nuttin, 1980; Nurmi, 1991; Zaleski, 1991). An exhaustive definition was formulated by Zaleski (1991). According to him, a goal is cognitively represented, possible to attain, possessing value and power regulating the future state of things to which a person strives to through her/his actions. The goal is a cognitive construct because it refers to a nonexistent future state of things which is represented in the human mind. Goals may be short-term, long-term or lifetime (Zaleski, 1991).

Life plans are ways and strategies of life goal fulfilment (Mądrzycki, 2002). According to Mądrzycki (2002), a life plan is an important main goal associated with many auxiliary goals and main principles for the operationalisation of the relevant goals. Mądrzycki does not consider the goal concept as being identical with the concept of a plan. In his view, a goal only specifies what a person strives to attain, whereas plans determine the ways and strategies of attaining the goal. Plans may be short-term and long-term.

Life decisions (concerning one's own future) are defined on the basis of psychological theory concerning decisions. A decision is understood as the selection of one option from among other available options (Kozielecki, 1975, 1992; Tyszka, 1986; Walesa, 1988). It consists of choosing one action from among the alternatives. It is a choice between at least two other eventualities. Decisions may be made either in a certain decisional situation (certain decisions), or in an uncertain decisional situation, that is, a risky one (uncertain/risky decisions) - Kozielecki, 1992; Walesa, 1988. The life decisions of adolescents (educational, professional, concerning personal life) are, in my view, undertaken in open, uncertain decisional situations (risky) (Czerwińska-Jasiewicz, 1997, 2005, 2015). They are also sequential decisions - which are comprised of not one but several interrelated decisions (e.g., choice of school, university, profession, and work). The life decisions of adolescents are, therefore, one of the most complex and difficult decisions that a person makes.

\section{Relationships between the main elements of adolescent's concept of their own life}

All the main elements of adolescent's concept of their own life briefly described above are closely interlinked (Czerwińska-Jasiewicz, 2005, 2015). The preferred lifestyle enables the formulation of goals and life plans associated with them. The fulfilment of goals and life plans allows the most preferred style (model) of life to be attained. However, in order for it to be possible to achieve the life goals and the fulfilment of the life plans associated therewith it is necessary to undertake autonomous and apt decisions concerning one's own life. Without taking such decisions, the fulfilment of life goals and plans in impossible.

The main factors on which the creation by adolescents of a concept of their own life significantly depends presented in Figure 1 are as follows (cf. Czerwińska-Jasiewicz, 2015, pp. 164-168):

1) The value system of adolescents (values cherished by them);

2) Social factors (e.g., general social situation in the country, the family and school situation);

3) The level of general development (development of thinking, personality, value system, worldview, and social development);

4) Individual characteristics (e.g., general intelligence, special skills and abilities, interests, attributes of personality, and temperamental characteristics).

Below is a brief overview of the significance of the factors outlined in the process of adolescents creating a concept of their own life.

The value system of a person is the main criterion for the creation of a concept of his/her own life (Inhelder, Piaget, 1970; Matusewicz, 1975; Mądrzycki, 2002; Czerwińska-Jasiewicz, 2005, 2015). Piaget (1970) thinks that 
values are the main criterion for the creation by adolescents of a project of their own life during adolescence. He believes that the "programme" of life of an adolescent is based on a set scale of values on which she/he places certain ideals and goals above others. This is possible thanks to the development of both formal thinking and of the personality during adolescence and most of all thanks to the individual value system which is intensively shaped during this life stage (Czerwińska-Jasiewicz, 2005, 2015; Cieciuch, 2007, 2013). The significance of the value system is also important not only when creating the general life concept but also when choosing the preferred lifestyle (Matusewicz, 1975; Mądrzycki, 2002), when formulating life goals and plans (Nuttin, 1980; Nurmi, 1991; Zaleski, 1991, 1994; Matusewicz, 1975; Mądrzycki, 2002), and when making decision concerning one's own future (Kozielecki, 1992; Tyszka, 1986).

Social factors. The most significant social factors that may be important in the process of adolescent's creating a concept of their own life include: the general social and economic situation of the country, the family situation, and the school situation (Czerwińska-Jasiewicz, 2015).

In the case of the general social and economic situation in the country, it is worth referring to Trempała's and Malmberg's $(1996,2000)$ reflections on this issue and to their theoretical model concerning the shaping of the future orientation of persons. According to Trempała and Malmberg, the future orientation of a person is shaped in a certain socio-cultural reality. The socio-cultural context affects a person's expectations concerning the future. The future orientation constitutes the grounds for a person to form a subjective theory of their own life. Therefore, the social context is a significant factor that may modify the impact of the value system on a person's creation of an own life concept, especially on the fulfilment of this concept (Trempała, Malmberg, 1996; Czerwińska-Jasiewicz, 1997, 2015; Oleszkowicz, Senejko, 2013).

Other significant social factors on which both the creation and the fulfilment of the own life concept by adolescents may depend on include the family and school situation of the adolescents (Czerwińska-Jasiewicz, 2015, 1997, 1991). The family living conditions (material, financial standing) and relationships with parents may have a significant impact on the creation and fulfilment of this concept. The school situation, most of all achievements at school, may also constitute a significant factor in the creation of one's own life concept but mainly on the process of its fulfilment.

The level of general development is a highly significant factor in the process of adolescents creating a concept of their own life (Czerwińska-Jasiewicz, 2015). The level of development in such areas as thinking, personality, value system, worldview, future orientation and social development are strong factors in this process (Czerwińska-Jasiewicz, 2005, 2015).

The development of thinking - the formation of formal operations is fundamental. This is because both development of future orientation as well as development of the personality, value system, worldview and social development all depend on the level of formal thinking. The development of the future orientation and the perspective of future time are closely related with the ability to formulate life goals and plans. The development of the system of values and worldview facilitates both the determination of the general concept of one's own life as well as defining its elements: selection of the preferred lifestyle, formulation of goals, plans, and decision making (Czerwińska-Jasiewicz, 2005, 2015). Social development is significant in determining one's concept of life. According to Piaget (1970), adolescent's project of their own life is closely related to the process of their "growth" into adult society and, in the views of Erikson (1997), with the search for their own individual place in society.

Individual characteristics. Individual characteristics like general intelligence, special skills and abilities, interests, personality traits and temperamental characteristics are of particular importance in the process of creating a concept of one's own life (Czerwińska-Jasiewicz, $2015,1991)$. It is difficult to find studies in literature concerning the significance of individual characteristics in the process of adolescents creating a concept of their own life. Attempts may be made, however, to substantiate their significance in this process on the basis of related studies concerning the significance of individual characteristics in the process of formulating goals and life plans and in the decision-making process. The importance of such individual characteristics as general intelligence, special skills and abilities, interests, personality traits and temperamental characteristics (Super, 1972; Czerwińska-Jasiewicz, 1991, 1997) in the process of making life decisions by adolescents was also emphasised. Moreover, the importance of the mentioned characteristics in the formulation of life goals and plans by adolescents was also stressed (Mądrzycki, 2002).

The factors that are decisive in the level and direction of personal achievements include such individual characteristics as general intelligence, special skills and abilities, interests, personality traits and temperamental characteristics (Super, 1972; Czerwińska-Jasiewicz, 1991). Apart from general intelligence and special skills and abilities, interests are one of the main factors on which the level and direction of personal achievements depend (Super, 1972). Interests are an important factor of intrinsic motivation which is crucial in the process of creating and fulfilling life plans (Mądrzycki, 2002).

A person's personality traits, especially those referred to as the Big Five (Costa \& McCrae, 2005, 2006) may be highly relevant to the process of adolescents creating a concept of their own life. Such traits as extraversion, neuroticism, agreeableness, stability, openness to experience and conscientiousness, significantly affect the functioning of a person in various scopes, which is why they can also play an important role in the process of formulating life goals and plans (Mądrzycki, 2002) and in the process of undertaking life decisions by adolescents (Kozielecki, 1975, 1992; Czerwińska-Jasiewicz, 1991, 1997). The personality traits mentioned above are linked to the temperamental characteristics of persons, thus, it 
can be expected that temperamental characteristics are also important in the process of creating a concept of one's own life (Mądrzycki, 2002; Costa \& McCrae, 2005, 2006). Unfortunately, there is a lack of both empirical and theoretical studies on the topic. Hence, they are only assumptions, albeit highly probable ones. Further in-depth empirical investigations of this topic are called for.

Several stages can be identified in the process of adolescents creating their own life concept, which have been presented in Figure 1.

The stages of adolescents creating a concept of their own life are as follows (cf. Czerwińska-Jasiewicz, 2015, p. 170):

1) Determination of the preferred lifestyle and its model,

2) Formulation of life goals,

3) Construing of life plans,

4) Making life decisions.

The course of this process can be presented in the following manner.

At the beginning of the process of creating one's own life concept, a person has a general vision and usually thinks of it in terms of how she/he would want to live, what model of life they would like to fulfil. This general preferred model of life is an indicator of their preferred lifestyle (Hejnicka-Bezwińska, 1991; Mądrzycki, 2002; Czerwińska-Jasiewicz, 2005, 2015). Once the general vision (model) of one's life has been outlined, it is possible to specify the main life goals whose fulfilment will enable the preferred lifestyle to be achieved. The next stage in this process is the formulation of life plans in relation to the main life goals. Plans are strategies for the fulfilment of life goals (Mądrzycki, 2002). The final stage of this process is determining which life decisions should be taken. The fulfilment of life goals and plans is not feasible without any decisions being made concerning one's own future (Czerwińska-Jasiewicz, 2005, 2015).

From the entirety of the considerations that have been presented, the next stages of this process of adolescents creating a concept of their own life are closely interlinked. Their sequence is also of importance.

\section{Information concerning own empirical research}

I would like to emphasise that the original extended model of adolescent's concept of their own life presented above is not merely a theoretical model but is based on many years of empirical research conducted by me (Czerwińska-Jasiewicz, 1997, 2005, 2015). Studies on adolescent's concept of their own life and its main elements (adolescent's preferred lifestyle, life goals, life plans and decisions concerning their own future) have been conducted by me and my master's and $\mathrm{PhD}$ students since the year 2000 to the present day, which is over 16 years in total. These investigations were mainly conducted at the Faculty of Psychology of the University of Warsaw (from 2000 to 2013), and from 2013 also in the Institute of Psychology of the Cardinal Stefan Wyszyński University in Warsaw, within master's and $\mathrm{PhD}$ tutorials and BST statutory research at University of Warsaw and at the Cardinal Stefan Wyszyński University. This research was and still is conducted on large groups of adolescents from Warsaw and other Polish cities. It has so far encompassed several thousand upper and lower secondary school pupils (secondary schools and vocational training schools). The study subjects were adolescents aged 14-16 years and 18-19 years. Thus, the studies were developmental in nature since groups of adolescents of different ages were compared.

The above studies concerned elements of the own life concept of adolescents like preferred lifestyle, life goals and different time periods, short- and long-term life plans and decisions concerning their own future. They also concerned the hierarchy of values held by adolescents. The relationships between these elements (goals and plans, plans and decisions, lifestyles and life goals and plans, etc.) was also investigated, as were the relationships between the value systems of adolescents and their preferred lifestyles, life goals and life plans.

The outcomes of subsequent studies were presented in the following forms:

1) Empirical articles $(2000,2001,2002,2003,2007$, and 2011);

2) Three author's own books in the form of monographs (1997, 2005, and 2015);

3) Presentations at national and international conferences (2000, 2001, 2002, 2003, 2005, 2007, 2009, and 2011).

The most important conclusions of my research on the subjectivity and autonomy of adolescents in the process of formulating life goals and plans and making life decisions have been presented below (Czerwińska-Jasiewicz, 2015, pp. 176-177):

1) Adolescents think about their future in general (92.1\%) in a distant time perspective (5-10 years);

2) The majority of the investigated adolescents (from $80 \%$ to over $90 \%$, depending on the time scope of the goals and the age), irrespective of their age and sex, hold life goals and formulate life goals both for short periods (one year, several years), and for longer periods of time (10 years), as well as lifetime ones.

3) The studied adolescents, regardless of their age and sex, consider their life goals as very important, lasting and possible to achieve. The chances of achieving them are high or at least average.

4) Most adolescents (75\% of adolescents aged 15 years and $89 \%$ of adolescents aged 18 years), regardless of their age and sex, formulate life plans for both short periods (a year-several years), and long periods of time (10 years).

5) The characteristics of the life plans of adolescents depend on their age. Such characteristics as concreteness, stability and openness to experience depend on the age of the adolescents - the older they are, the more specific, lasting and open to experience are their plans. The assessment of the possibilities for the fulfilment of plans, on the other hand, is usually high, irrespective of the age of the adolescents. No sexual differentiation occurs in terms of the characteristics of the plans. 
6) The life decisions of adolescents (educational and professional) are generally very certain, irrespective of their age. They are, in their own opinion, very independent.

7) The autonomy of the life decisions of adolescents is, in their view, extensive. However, this is dependent on their age. The autonomy of decisions compared to parental influence is significantly higher in the group of older pupils (school leavers) than in younger pupils (lower secondary school pupils). The autonomy of the decisions of adolescents in relation to their peers and teachers is high, regardless of age. In the opinion of the pupils themselves, their educational and professional decisions are independent of the influence of their peers and teachers.

A tendency can be seen on the basis of the described results in terms of the subjectivity and autonomy of goals, and the life plans and decisions of adolescents. Both the subjectivity and autonomy of adolescents in this scope increases with age. This is connected with the general development of adolescents, with the development of formal thinking, with the growth of their personality (process of individuation) and with social development ("growth" into society).

\section{Main conclusions from the presented considerations}

The most important conclusions that can be deduced on the grounds of the deliberations presented above are as follows:

1) Concluding from the theoretical studies (Inhelder, Piaget, 1970; Niemczyński, 1980, 1988) as well as empirical research (Zaleski, 1991; Trempała \& Malmberg, 1996; Czerwińska-Jasiewicz, 1997, 2005, 2015), the creation by adolescents of a concept of their own life is a specific and widespread phenomenon during this stage of development;

2) The creation of a concept of one's own life is closely related to general development during adolescence, especially with the development of thinking, personality, value system, worldview, social development and the development of the future orientation (Inhelder, Piaget, 1970; Trempała, 2000; Czerwińska-Jasiewicz, 2005, 2015). This process is also closely linked with important needs of this life stage which include the strong need for autonomy and independence and the search for one's own individual place in society (Inhelder, Piaget, 1970; Erikson, 1997).

3) The main elements of adolescent's concept of their own lives include the preferred lifestyle, life goals, and life plans and decisions concerning the future (Czerwińska-Jasiewicz, 2005, 2015).

4) The most important factors that can impact the creation by adolescents of a concept of their own life are the cherished values (Inhelder, Piaget, 1970), as well as social factors, and factors linked with general development and individual characteristics (Czerwińska-Jasiewicz, 2015).

5) The following consecutive stages can be identified in the process of adolescents creating a concept of their own life (Czerwińska-Jasiewicz, 2005, 2015): Selection of the preferred lifestyle, choice of life goals, formulation of life plans and making decisions concerning one's own future. They are also closely interlinked.

6) The creation by adolescents of a concept of their own life can be deemed as a manifestation of their subjectivity and autonomy (Inhelder, Piaget, 1970; Niemczyński, 1980, 1988).

I will attempt to justify this last conclusion in further reflections herein.

\section{Creation of the concept of one's own life by adolescents manifestation of their subjectivity and autonomy}

I will return to the statement of Piaget (1970) that the essential criterion of adolescence is "growth" of adolescents into adult society. What does this consist of according to Piaget? According to him (1970, p. 361): "An adolescent is an individual that starts to consider themselves equal to adults and begins to judge them on the basis of this equality and complete reciprocity". Also, an adult, according to Piaget (1970, p. 361) is an individual that is still developing but starts thinking about the future. She/he is, therefore, an individual that starts to add a life programme for their future actions and activities to their current actions and activities. In the views of Piaget (1970, p. 373), the life plan is mainly a value scale on which they place certain ideals above others and subject other values/means to the goals that they deem to be lasting.

The own life programme of adolescents is also, in the opinion of Piaget, an affirmation of the autonomy of the young person who considers her/himself to be equal to adults. Based on the presented views, this thesis can be justified by the fact that the adolescent is already a separate subject considering her/his life programme. They begin to create their own life concept and formulate their life plans and goals increasingly independently. This life programme of an adolescent testifies, according to Piaget, to her/his autonomy, or at least to their striving to autonomy in the process of its creation. Piaget considers their attitude in relation to adults, the attitude of equality and complete reciprocity, to evidence the need and striving to autonomy of adolescents. Transformations in the thinking of adolescents, the move from concrete to formal thinking and the process of determining one's own identity by adolescents closely related with the individuation process (Jarymowicz, 1988) that is intensively taking place in adolescence plays a strong role in this process.

A similar reasoning was presented by Niemczyński (1980, 1988, p. 227, who argued that young people create a project during adolescence of the structure of their own self as the subject of actions in the system of programmes and goals created by them. The process of personalisation of human actions occurs in youth and adolescence (Niemczyński, 1980, 1988). The adolescent possesses a great number of goals and plans during this time. Thus, they are faced with the necessity of hierarchically 
ordering them. These statements unequivocally indicate the subjectivity and autonomy of adolescents in the process of the creation of their own life concept and in the scope of formulating their own life goals and plans.

Also, numerous empirical studies on life plans and goals (Nuttin, 1980; Nurmi, 1991; Zaleski, 1991; Trempała, Malmberg, 1996; Liberska, 2004; Katra, 2008; Czerwińska-Jasiewicz, 2005, 2015) and decisions of adolescents concerning their own future (Rydz, 1995; Czerwińska-Jasiewicz, 1997) indicate that the formulation of goals, the creation of life plans and life decisionmaking by adolescents is subjective and autonomous in nature. Adolescents generally consider their goals, plans and decisions as independent and autonomous from other people's influence (parents, peers, teachers). My own research findings on the life goals, plans and decisions of adolescents also support these outcomes (Czerwińska-Jasiewicz, 1997, 2005, 2015). The most important conclusions of my research on the subjectivity and autonomy of adolescents in the process of formulating life goals and plans and making life decisions have been presented in point 4 of this article (Czerwińska-Jasiewicz, 2015, pp. 17-18).

\section{Ending}

This article presents a discussion on the issue of the creation by young people of a concept of their own lives during adolescence. The creation of this concept has been acknowledged as a sign of their subjectivity and autonomy. Attempts were made to substantiate this thesis on the basis of theoretical concepts (Niemczyński, 1980, 1988; Inhelder, Piaget, 1970) and empirical studies (Nuttin, 1980; Nurmi, 1991; Zaleski, 1991; Trempała, 1996, 2000; Liberska, 2004; Katra, 2008; Czerwińska-Jasiewicz, 2005, 2015). An original extended model of adolescent's concept of their own life was also presented (Czerwińska-Jasiewicz, 2015).

The presented deliberations allow for the statement to be made that the creation by adolescents of a concept of their own life during adolescence results from the general development (Czerwińska-Jasiewicz, 2015) during adolescence (development of thinking, personality, and social development) of the process of individuation which is intensively taking place during this stage in life (Jarymowicz, 1988) and is a manifestation of the subjectivity and autonomy of adolescents being formed during adolescence (Inhelder, Piaget, 1970; Niemczyński, 1980, 1988).

\section{References}

Adamiec, M. (1992). Podmiotowość - formy i zmiany [Subjectivity - forms and transformations]. In Z. Ratajczak (Ed.), Psychologiczne problemy funkcjonowania człowieka $w$ sytuacji pracy [Psychological problems of human functioning in the workplace context]. Vol. 10 (19): Podmiotowość człowieka. Szanse rozwoju i zagrożenia [Human subjectivity. Opportunities for development and risks] (11-31). Katowice: Uniwersytet Śląski.

Baltes, P.B. (1987). Theoretical propositions of life span developmental psychology: On the dynamics between growth and decline. Developmental Psychology, 23, 611-626.
Cieciuch, J. (2013). Ksztaltowanie się systemu wartości od dzieciństwa do wczesnej dorostości [Shaping of the value system from childhood to early adulthood]. Warsaw: Liberi Libri Publishing House.

Costa, P.T., McCrae, R.R. (2005). Osobowość człowieka dorostego [Personality of an adult]. Krakow, WAM.

Czerwińska-Jasiewicz, M. (1991). Psychologiczne problemy wyboru zawodu [Psychological problems in choosing a profession]. Warsaw: Wydawnictwo Uniwersytetu Warszawskiego.

Czerwińska-Jasiewicz, M. (1997). Decyzje młodzieży dotyczace własnej przyszłości (uwarunkowania psychospołeczne) [Young people's decisions concerning their future (psychosocial determinants)]. Warsaw: Oficyna Wydawnicza Wydziału Psychologii UW.

Czerwińska-Jasiewicz, M. (2000). The life goals and plans of adolescents in the context of future orientation development. Presentation during the European Conference on Developmental Psychology (ECDP), Jena, Germany.

Czerwińska-Jasiewicz, M. (2001a). The life styles and systems of values of adolescents in relation to their type and direction of education. Presentation during the European Conference on Developmental Psychology (ECDP), Uppsala, Sweden.

Czerwińska-Jasiewicz, M. (2001b). Style życia i systemy wartości młodzieży w zależności od typu i kierunku kształcenia [Lifestyles and value systems of adolescents depending on the type and field of study]. Psychologia Rozwojowa, 6, 3-4, 257-270.

Czerwińska-Jasiewicz, M. (2001c). The life goals of adolescents in the changing social situation in Poland. Studia Jagellonica Humani Cultus Progressus, 5, 1(15), 53-69.

Czerwińska-Jasiewicz, M. (2003a). Cele i plany życiowe młodzieży w kontekście rozwoju orientacji przyszłościowej [Life plans and goals of adolescents in the context of the development of the future orientation], In L. Wojciechowska (Ed.), Spostrzeganie zjawisk świata społecznego przez dzieci, młodzież $i$ młodych dorostych [Perception of social phenomena by children, adolescents and young adults] (129-148). Warsaw: Wydawnictwo Uniwersytetu Warszawskiego.

Czerwińska-Jasiewicz, M. (2003b). The role models of adolescents in the context of their value systems and life styles. Presentation during the European Conference on Developmental Psychology (ECDP), Milan, Italy.

Czerwińska-Jasiewicz, M. (2004). Life goals of adolescents in the context of their system of value. Presentation during the International Conference of ISSBD (International Society of Study on Behavioural Development), Ghent, Belgium.

Czerwińska-Jasiewicz, M. (2005). Rozwój psychiczny młodzieży a jej koncepcje dotyczace własnego życia [Psychical development of adolescents and their own life conception]. Warsaw: Wydawnictwo Instytutu Psychologii PAN

Czerwińska-Jasiewicz, M. (2007). Adolescent's concepts on their own lives - A new research model and synthesis proposal. Polish Psychological Bulletin, vol. 38, No. 3, 149-155.

Czerwińska-Jasiewicz, M. (2011a). Wspieranie młodzieży w zakresie samopoznania, planowania własnego życia oraz podejmowania decyzji dotyczących własnej przyszłości [Supporting adolescents in the field of self-cognizance, own life planning and making decisions concerning own future]. In J. Trempała (Ed.) Psychologia Rozwoju Człowieka. Warsaw: Wydawnictwo Naukowe PWN, Ch. 18, Part III.

Czerwińska-Jasiewicz, M. (2011b). The significance of Adolescent's value system in creating a concept of their own life. Polish Psychological Bulletin, vol. 42, No. 4, p. 1-10.

Czerwińska-Jasiewicz, M. (2011c). Adolescents life goals depending on the size and cohesion of their self-esteem. Presentation during the European Conference on Developmental Psychology (ECDP), Bergen, Norway.

Czerwińska-Jasiewicz, M. (2015). Psychologia rozwoju młodzieży w kontekście biegu ludzkiego życia [Developmental psychology of adolescents during the life course]. Warsaw: Wydawnictwo Difin.

Erikson, E.H. (1950). Childhood and Society. New York: Norton.

Erikson, E.H. (1997). Dzieciństwo i społeczeństwo. Poznan: Dom Wydawniczy Rebis.

Havighurst, R.J. (1972). Developmental tasks and education, Ed. 3. New York: D. McKay. 
Hejnicka-Bezwińska, T. (1991). Orientacje życiowe młodzieży. Bydgoszcz: Wydawnictwa Wyższej Szkoły Pedagogicznej.

Inhelder, B., Piaget, J. (1970). Od logiki dziecka do logiki młodzieży [From the logic of a child to the logic of an adolescent]. Warsaw: Państwowe Wydawnictwo Naukowe.

Jarymowicz, M. (Ed.) (1988). Studia nad spostrzeganiem relacji ja-inni: tożsamość, indywiduacja - przynależność [Studies on the perception of the I-Others relationship: identity, individuation-belonging]. Warsaw: Ossolineum.

Katra, G. (2008). Aktywność prospektywna młodzieży [Prospective activity of adolescents]. Warsaw: Wydawnictwo Instytutu Psychologii PAN.

Kozielecki, J. (1975). Psychologiczna teoria decyzji [Psychological theory of decisions]. Warsaw: Państwowe Wydawnictwo Naukowe.

Kozielecki, J. (1992). Podejmowanie decyzji [Decision making]. In T. Tomaszewski (Ed.), Psychologia ogólna [General Psychology] (155-185). Warsaw: Wydawnictwo Naukowe PWN.

Liberska, H. (2004). Perspektywy temporalne mtodzieży [Temporal perspectives of adolescents]. Wybrane uwarunkowania. Poznan: Wydawnictwo Naukowe UAM.

Luyckx, K., Goossens, L., Soenens, B., Beyers, W. (2006b). Unpacking commitment and exploration: validation of an integrative model of adolescent identity formation. Journal of Adolescence, 29, 361-278.

Marcia, J.E. (1980). Identity in adolescence. In J.J. Adelson (Ed.). Handbook of Adolescent Psychology (159-187). New York: John Wiley $\&$ Sons.

Matusewicz, Cz. (1975). Psychologia wartości [Psychology of values]. Warsaw: Państwowe Wydawnictwo Naukowe.

Mądrzycki, T. (2002). Osobowość jako system tworzacy i realizujacy pla$n y$ [Personality as a system creating and fulfilling plans]. Gdansk: Gdańskie Wydawnictwo Psychologiczne.

Niemczyński, A. (1980). Modele indywidualnego rozwoju czlowieka [Models of individual human development]. Krakow: Wydawnictwo Uniwersytetu Jagiellońskiego.

Niemczyński,A. (1988). Procesy rozwojowe człowieka w pełnym cyklu życia indywidualnego [Human developmental processes in the full individual life course]. In M. Tyszkowa (Ed.), Rozwój psychiczny czlowieka w ciagu życia [Human psychological development in the life course] (223-233). Warsaw: Państwowe Wydawnictwo Naukowe.

Niemczyński, A. (2000). Szansa na powrót ideałów do rozwoju poznawczego [Opportunity for ideals to return to cognitive development]. Psychologia Rozwojowa, 5, 1-2, 11-25.

Nurmi, J.E. (1991). How do adolescents see their future? A review of the development of the future orientation and planning. Developmental Review, 11, 1-59.

Nuttin, J. (1980). Motivation et perspective d 'avenir. Louvain: Presses Universitaires.
Obuchowska, I. (2000). Adolescencja [Adolescence]. In B. Harwas-Napierała, J. Trempała (Ed.). Psychologia rozwoju czlowieka (vol. 2, 163-201). Warsaw: Państwowe Wydawnictwo Naukowe.

Obuchowski, K. (1977). Autonomia jednostki a osobowość [Individual autonomy and personality]. In J. Reykowski, O.W. Owczynnikowa, K. Obuchowski (Ed.). Studia z psychologii emocji, motywacji $i$ osobowości [Studies on the psychology of emotions, motivation and personality] (pp. 77-101). Wroclaw: Zakład Narodowy im. Ossolińskich.

Obuchowski, K. (1995). Przez galaktyke potrzeb [Crossing a galaxy of needs]. Poznan: Zysk i S-ka.

Oleszkowicz, A., Senejko, A. (2013). Psychologia dorastania - zmiany rozwojowe w dobie globalizacji [Adolescent psychology - developmental changes in the age of globalisation]. Warsaw: Wydawnictwo Naukowe PWN.

Podsiad, A., Więckowski, Z. (Ed.) (1983). Mały stownik terminów i pojęć filozoficznych dla studiujacych filozofię chrześcijańska [Pocket glossary of philosophical terms and concepts for Christian philosophy students]. Warsaw: Instytut Wydawniczy PAX

Reykowski, J. (1988). Podmiotowość - szkic problematyki [Subjectivity an outline of the issues]. In P. Buczkowski, R. Cichocki (Ed.). Podmiotowość: możliwość - rzeczywistość - konieczność [Subjectivity: possibility - reality - necessity]. Poznan: Redakcja Wydawnictw Ośrodka Analiz Społecznych ZMW.

Rydz, E. (1995). The development of life planning and related decision making during adolescence. Polish Quarterly of Developmental Psychology, 1, 2, 83-90.

Straś-Romanowska, M. (1999). Rozwój osobowy. Próba konceptualizacji problemu w nawiązaniu do psychologii life-span [Personal development. An attempt to conceptualise the issue in relation to lifespan psychology]. Forum Psychologiczne, 4, 115-127.

Super, D. (1972). Psychologia zainteresowań [Psychology of interests]. Warsaw: Państwowe Wydawnictwo Naukowe.

Trempała, J., Malmberg, L.E. (1996). Dorosłość w oczekiwaniach młodzieży polskiej i fińskiej [Adulthood in the expectations of Polish and Finnish adolescents]. Forum Psychologiczne, 1, 1-2, 59-70.

Trempała, J. (2000). Modele rozwoju psychicznego. Czas i zmiana [Models of psychological development. Time and change]. Bydgoszcz: Wydawnictwo Uczelniane Akademii Bydgoskiej im. Kazimierza Wielkiego.

Trempała, J., Malmberg, L.E. (2002). Future orientation of adolescents. Frankfurt, New York, Oxford, Vienna: Peter Lang Publishers.

Walesa, Cz. (1988). Podejmowanie ryzyka przez dzieci i młodzież [Risk taking by children and adolescents]. Development research. Lublin: Redakcja Wydawnictw KUL.

Zaleski, Z. (1991). Psychologia zachowań celowych [Psychology of goal-directed behaviour]. Warsaw: Państwowe Wydawnictwo Naukowe.

Zaleski, Z. (1994). Psychology of future orientation. Lublin: Towarzystwo Naukowe KUL. 